\title{
Metamorphic Changes of Dermis in Skin of Frog Larvae Exposed to Thyroxine ${ }^{1}$
}

\author{
Norman E. Kemp \\ Department of Zoulogy, The Universily of Michigan, \\ Ann Arbor, Michigan
}

Accepted October 22, 1962

\section{INTRODUCTION}

Skin in the tadpole of anuran larvae prior to metamorphosis is composed of two layers of epidermal cells (Leeson and Threadgold, 1961; Chapman and Dawson, 1961; Edds and Sweeny, 1960, 1962), a laminated basement lamella, and a layer of dermal mesenchyme cells apposed to the underside of the basement lamella. An adepidermal space and membrane (Salpeter and Singer, 1959, 1960) separate epidermis from the dermal basement lamella. Weiss and Ferris (1954) first observed that mesenchyme cells migrate into the basement lamella as metamorphosis begins. Invasion of the lamella has been reported to begin about Taylor-Kollros stage XI or XII (Kemp, 1961b) and to proceed until mesenchyme cells move entirely through the lamella and cause it to become detached from the adepidermal membrane at stages XV-XVI. Subsequently a population of cells constituting the stratum spongiosum develops beneath the adepidermal membrane and the basement lamella becomes the deeper-lying stratum compactum or "dermal lamella" of the adult dermis. New polymerization of collagenous fibers and ground substance results in deposition of the adult basement membrane between the adepidermal membrane and the stratum spongiosum.

Generalized metamorphic changes can be induced in amphibian larvae by exposing them to thyroxine or other thyroid hormones (Kollros, 1959; Pitt-Rivers and Tata, 1959). Local metamorphic changes can be induced by implanting pellets of thyroxine mixed with

${ }^{1}$ This investigation was supported by grants from the United States Public Health Service (RG 5867- $\mathrm{C}_{3}$ ), the National Science Foundation (G-19447), and the Michigan Memorial-Phoenix Project (no. 206). 
cholesterol (Kaltenbach, 1959). The investigation reported here was undertaken to learn what submicroscopic changes could be detected in dermal elements of larvae exposed to a strong concentration of thyroxine.

\section{MATERIALS AND METHODS}

Tadpoles of Rana pipiens were staged by the descriptions of Taylor and Kollros (1946). A stock solution of $1 \mathrm{mg}$ thyroxine per liter of conditioned tap water was stored in a refrigerator at about $10^{\circ} \mathrm{C}$. For an experiment, individual larvae at stages III-VII were transferred to finger bowls containing fresh thyroxine solution and kept thereafter at room temperature. Dilutions of the stock solution with final concentrations of $1,2,5$, and $10 \mu \mathrm{g}$ per liter were first tested for their effects on metamorphosis, but these low dilutions were abandoned when it was learned that animals would survive up to 7-8 days and that much more rapid changes could be induced by immersion in the stock solution itself. The skin in this relatively short time goes through many of the changes characteristic of normal metamorphosis.

At daily intervals after immersion in the thyroxine solution, skin from the region of the head over the hindbrain was excised and fixed in Caulfield's osmic acid fixative and prepared for embedding in Epon 812. The remainder of the animal was fixed in Bouin's fixative and prepared for paraffin embedding. Sections of Epon-embedded tissue were cut either with a Porter-Blum microtome or an LKB ultratome. They were mounted on Formvar-coated grids, then stained in saturated uranyl acetate for an hour before being rinsed in running tap water. An RCA EMU 3E electron microscope was used for microscopy.

\section{RESULTS}

The earliest experiment of the type reported here was done with tadpoles raised in the laboratory after artiticial ovulation and fertilization in the fall of 1960. Animals exposed to the stock solution of thyroxine at stages III-V, as previously reported by abstract (Kemp, 1961a) lived up to 7 days. For the first 3 days the basement lamella did not appear to be significantly altered, but by the fourth day it was apparent that mesenchyme cells had moved outward into the membrane. During days 5-7 more cells evidently became interposed between layers of the basement lamella, but the membrane did not 
become detached from the adepidermal membrane. Micrographs documenting these changes have not been published because it was recognized that embedding the tissue in methacrylate had resulted in poor preservation of cellular detail.

Animals used in the experiment described in this paper were collected from an outdoor swimming pool in June of 1962. When brought to the laboratory the tadpoles used for exposure to thyroxine were already up to $37-49 \mathrm{~mm}$ long and according to the development of their hind limbs were at stages VI-VIII. When the experiment was begun, we were not sure of the species of these collected animals because of their size so early in the summer. We tentatively identified them as larvae of Rana clamitans which had wintered over from the previous summer. By raising some of them to metamorphosis, however, we discovered that they were spotted and obviously belonged to Rana pipiens.

\section{Control, Not Exposed to Thyroxine}

There were about 29 layers in the basement lamella of this specimen (Fig. 1). Even in this control animal which was not exposed to thyroxine, there were protoplasmic processes out in the basement lamella. This is not surprising, since it is known that by Shumway stage 25 elongate processes may extend into the lamella either from basal epidermal cells or mesenchyme cells (Edds and Sweeny, 1962).

Despite the presence of pseudopodia within the membrane at stage VII, the main bodies of mesenchymal cells had not migrated from their early location spread out beneath the basement lamella. One type of mesenchymal cell produces large vacuoles (Fig. 1), which by their hydrostatic pressure may assist the process of tight packing

FIG. 1. Control specimen not exposed to thyroxine, $44 \mathrm{~mm}$ long at stage VII when fixed. Section shows portion of basal epidermal cell $(E)$, basement lamella $(B L)$, and underlying mesenchyme cell $(M)$. Protoplasmic process $(p)$ from mesenchyme cell extends into basement lamella. Vertically oriented channels $(c)$ containing homogeneous material and fine filaments $(f)$ also in basement lamella. Large vacuoles $(v)$ in mesenchyme cell. Magnification: $\times 10,800$.

FIG. 2. One-day specimen, $44 \mathrm{~mm}$ long at stage VII when exposed to thyroxine, no change when fixed. Protoplasmic process $(p)$ appears to be expanding horizontally in basement lamella. Below this process are fine filaments $(f)$ oriented vertically. Similar filaments are seen in the channel $(c)$ extending down from the epidermis $(E)$. Vertically oriented column of filaments below lamella runs between mesenchyme cells $(M)$. Magnification: $\times 17,855$. 

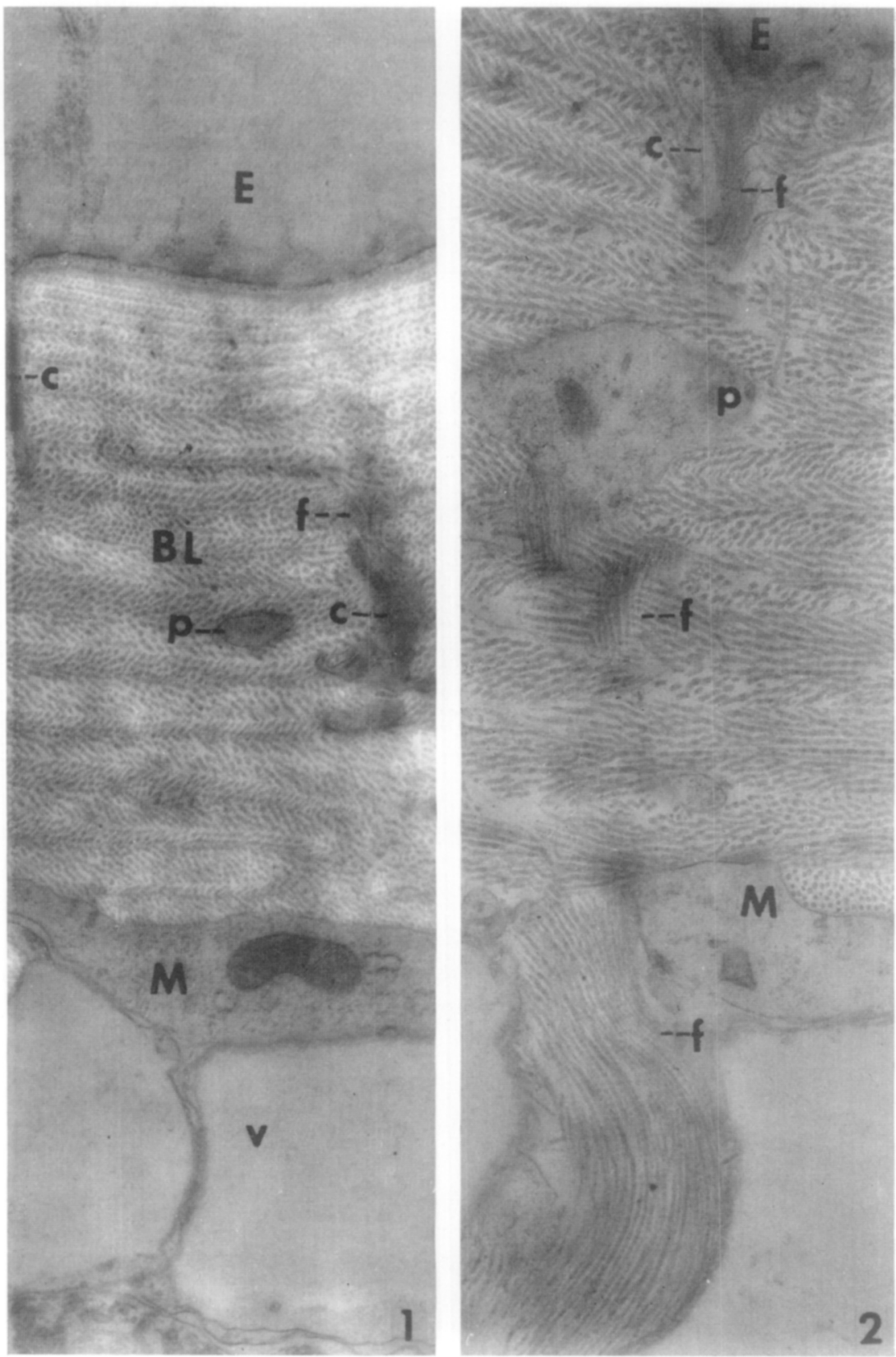
of the flat layers of the basement lamella during larval growth. Dermal cells which extend processes outward into the substance of the lamella are distinguished as stellate cells (Edds and Sweeny, 1962). They have the morphology of "fibrocytes" (Weiss and Ferris, 1954) or "fibroblasts" (Kemp, 1961b). Another cell type tentatively identified previously as a "melanoblast" (Kemp, 1961b) occurs in the population of mesenchymal cells beneath the basement lamella, but I have never observed it extending into the lamella until after the pioneering cells ("fibroblasts") have opened migratory channels. This cell type, containing light vesicles and dark granules, resembles the lipophores identified by Mishima et al. (1962) in goldfish scales. It may indeed be a chromatophore, possibly a xantholeucophore, distinct from the melanophore. The latter when differentiated is readily identified by its dark inclusions of melanin.

Vertically oriented within the basement lamella are channels (Fig. 1) which contain a dense amorphous substance and also fine filaments oriented along their axis. These channels probably consist of extracellular materials, i.e., ground substance and filaments, closely associated with elongate processes of epidermal cells extending down into the basement lamella or with processes directed outward from the stellate dermal cells into the lamella. The fine filaments along the channels could be newly polymerized fibrils developing from precursor units; or they could be the residuum resulting from the digestive action of a collagenase on larger filaments previously built into the structure of the membrane.

\section{One Day in Thyroxine}

The tip of an enlarged protoplasmic process associated with vertically oriented filaments of varying diameters is seen in Fig. 2.

FIG. 3. Two-day specimen, $47 \mathrm{~mm}$ long at stage VI when exposed, $45 \mathrm{~mm}$ long and still at stage VI when fixed. Mesenchyme cell $(M)$ embedded in basement lamella. Nucleus $(n)$, mitochondria $(m)$, and abundant vesicles (ve) of endoplasmic reticulum are prominent features. Protoplasmic processes at $p$. Magnification: $\times 14,400$.

FIG. 4. Four-day specimen, $46 \mathrm{~mm}$ long at stage VII when exposed, $35 \mathrm{~mm}$ long at stage VIII when fixed. Mesenchyme cell $(M)$ with large nucleus $(n)$ embedded in basement lamella. Cell in epidermis $(E)$ contains dark structures which may be modified mitochondria plus abundant small vesicles. Magnification: $\times 14,000$. 

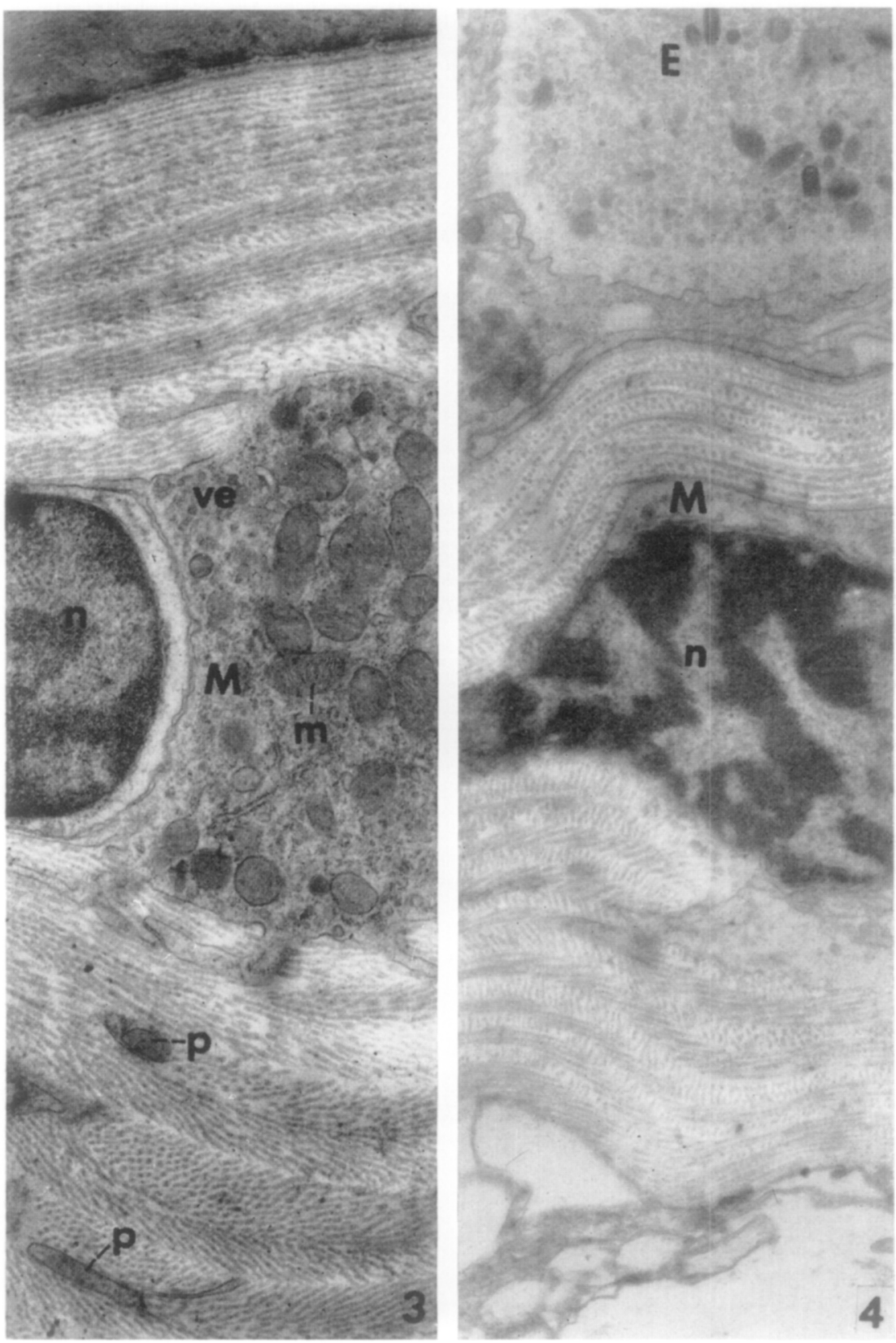
The process appears to be expanding laterally and displacing filaments of several plies of the lamella. Parts of cells containing nuclei have not been observed in the lamella fixed but 1 day after exposure to thyroxine.

\section{Two Days in Thyroxine}

Cell bodies including nuclei were embedded in the basement lamella fixed 2 days after initial exposure. Abundant mitochondria and many small vesicles in the cytoplasm of these cells (Fig. 3) indicate that they are metabolically active. What appears to be a nerve ending protrudes into the base of the lamella in Fig. 3.

\section{Three to Four Days in Thyroxine}

Invading cells had elongated horizontally between plies, but still had not separated the basement lamella from its anchorage at the adepidermal membrane (Fig. 4). A basal epidermal cell in Fig. 4 contains many small vesicles and a number of dark inclusions which may be modified mitochondria. Such a cell has not been observed in the skin of normal, untreated tadpoles. Epidermal changes a fter exposure to high concentrations of thyroxine will not be reported in detail here, but it is worthy of note that outer cells of the epidermis undergo progressive flattening as the time of exposure to thyroxine increases.

\section{Five to Seven Days in Thyroxine}

Mesenchyme cells had moved up so that by 5 days only two or three plies separated them from the adepidermal membrane. Vesi-

Fig. 5. Five-day specimen, $48 \mathrm{~mm}$ long at stage VII when exposed, $41.5 \mathrm{~mm}$ at stage IX-X when fixed. Mesenchyme cells $(M)$ are separated from epidermis $(E)$ only by 3-4 layers of basement lamella. The mesenchyme cell containing vesicles (ve) and dark granules ( $g$ ) is probably either a melanoblast or a lipophore (xantholeucophore?). Vertically oriented channel $(c)$ with fine filaments adjacent to mesenchyme cell within basement lamella. Magnification: $\times 9415$.

Fig. 6. Six-day specimen, $44 \mathrm{~mm}$ long at stage VI when exposed, $18 \mathrm{~mm}$ long at stage IX when fixed. Mesenchyne cells $(M)$ have moved very close to epidermis, although 1-2 layers of basement lamella still underlie the adepidermal membrane bordering the epidermis; thus a stratum spongiosum of connective tissue cells now separates the epidermis from the deep-lying basement lamella $(B L)$, which may now be called the dermal lamella or stratum compactum. Magnification: $\times 14,000$. 

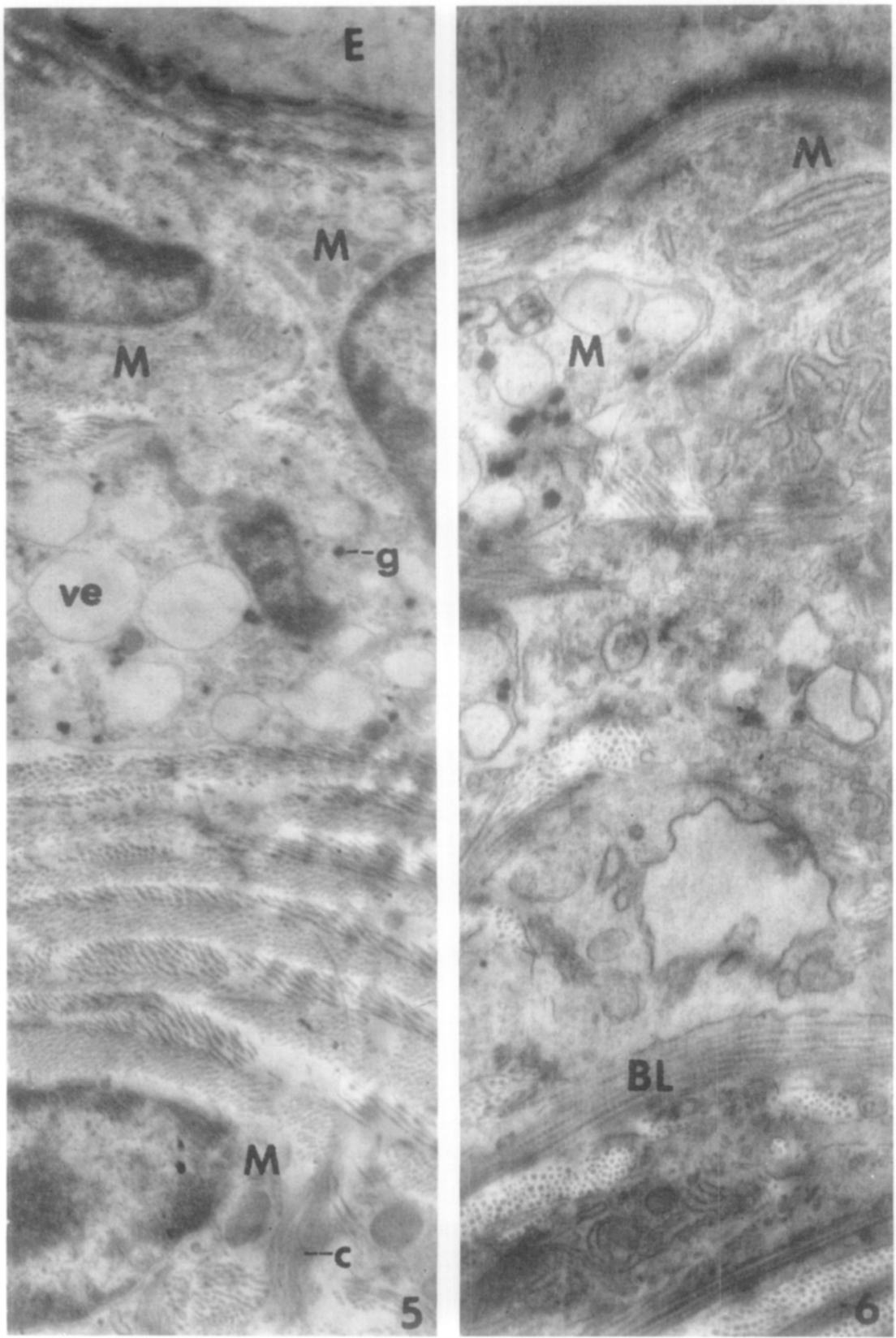
culated cells (melanoblasts or lipophores?) and stellate cells (fibroblasts?) are both evident in Fig. 5 toward the outer edge of the lamella. By 6 days mesenchyme cells had accomplished separation of the basement lamella from the adepidermal membrane and thus had established a definite stratum spongiosum, illustrated in Fig. 6. There were no significant advances in this region at 7 days. Some mesenchyme cells remain embedded (Fig. 6) in the basement lamella after it becomes detached to become the stratum compactum or dermal lamella.

\section{DISCUSSION}

It is evident from the results described that thyroxine stimulates mesenchymal cells to migrate through the basement lamella and establish the stratum spongiosum much as they do in normal metamorphosis. How the hormone accomplishes this mobility by the invading cells is not yet known. It is possible that the hormone itself might cause depolymerization of ground substance in the basement lamella, thereby enabling the natural mobility of mesenchymal cells to effect the observed pattern of invasion. A second possibility is that the high rate of metabolism induced by thyroxine may result in a lowered $\mathrm{pH}$ in the extracellular milieu of dermal cells (cf. Kaltenbach, 1959). This condition might cause depolymerization of the membrane. Still another possibility is that the hormone induces mesenchymal cells and perhaps epidermal cells to produce enzymes (perhaps hyaluronidase, Weiss and Ferris, 1954) which depolymerize either ground substance alone or ground substance plus collagenous filaments, thereby opening channels for cellular invasion.

The observed channels, containing osmiophilic amorphous material and fine filaments oriented perpendicular to the plies of the basement lamella (Figs. 1-3), may have a greater significance than that of merely serving as highways for migration of dermal cells. They could also serve as avenues for moving in precursor materials for construction of ground substance, filaments, or both. If the basement lamella thickens both by addition of new layers at its outer surface next to the epidermis and also by interstitial growth within layers already formed, as suggested by Edds and Sweeny (1962), these channels might be principal routes for diffusion of precursor substances contributed either by dermal or epidermal cells. Closer attention to the morphology and functions of these vertically oriented components of 
the basement lamella may prove rewarding. They may facilitate interactions between epidermis and dermis "with regard to the site of appearance of intercellular materials," of the type envisioned by Wessells (1962).

\section{SUMMARY}

Larvae of Rana pipiens immersed in a strong thyroxine solution at Taylor-Kollros stages VI-VIII survived up to 7-8 days. Samples of head skin were fixed daily and prepared for electron microscopy.

Protoplasmic processes from mesenchyme cells protrude into the basement lamella in control animals not exposed to thyroxine and in those exposed but 1 day. Channels containing ground substance and fine filaments are oriented vertically in the lamella.

By 2 days after immersion cell bodies of mesenchyme cells have moved into the basement lamella. Mesenchyme cells are found closer to the epidermis after 3-4 days.

By days 5-7 mesenchyme cells have moved outward to form the stratum spongiosum separating basement lamella from epidermis.

Dr. Paul Weiss introduced me to the problems encountered in analyzing differentiation of skin. It is a great pleasure to have this opportunity to contribute to this volume dedicated to him. I wish also to acknowledge the expert assistance rendered by my research assistant, Mrs. Nancy L. Istock.

\section{REFERENCES}

Chapman, G. B., and Dawson, A. B. (1961). Fine structure of the larval anuran epidermis, with special reference to the figures of Eberth. J. Biophys. Biochem. Cytol. 10, 425-435.

EdDs, M. V., JR., and SweEny, P. R. (1960). Chemical and morphological differentiation of the basement lamella. In "Synthesis of Molecular and Cellular Structure" (19th Growth Symposium) (D. Rudnick, ed.), pp. 111-138. Ronald, New York.

Edns, M. V., Jr., and Sweeny, P. R. (1962). Development of the basement lamella. In "Electron Microscopy" (Fifth International Congress for Electron Microscopy) (S. S. Breese, Jr., ed.), Vol. 2, QQ-2. Academic Press, New York.

KaltenbaCH, J. C. (1959). Local action of thyroxine on amphibian metamorphosis. IV. Resorption of the tail in anuran larvae effected by thyroxinecholesterol implants. J. Exptl. Zool. 140, 1-18.

Kemp, N. E. (1961a). Metamorphic changes in the basement lamella of the skin of frog larvae exposed to thyroxine. Anat. Record 139, 245.

KEMP, N. E. (1961b). Replacement of the larval basement lamella by adult-type basement membrane in anuran skin during metamorphosis. Develop. Biol. 3, 391-410. 
Kollkos, J. J. (1959). Thyroid gland function in developing cold-blooded vertebrates. In "Comparative Endocrinology" (A. Corbman, ed.), pp. 340-350. Wiley, New York.

Leeson, C. R., and Threadgold, L. T. (1961). The differentiation of the epidermis in Rana pipiens. Acta Anat. 44, 159-173.

Mishima, Y., Loud, A. V., and Schaub, F, F., Jr. (1962). Electron microscopy of "premelanin." J. Invest. Dermatol. 39, 55-62.

Pitt-Rivers, R., and Tata, J. R. (1959). "The Thyroid Hormones." Pergamon, New York.

SALpeter, M. M., and Singer, M. (1959). The fine structure of the adepidermal reticulum in the basal membrane of the skin of the newt, Triturts. J. Biophys. Biochem. Cytol. 6, 35-40.

Salpe'ter, M. M., and Singer, M. (1960). Differentiation of the submicroscopic adepidermal membrane during limb regeneration in adult Triturus, including a note on the use of the term basement membrane. Anat. Record 136, 27-40.

TAylon, A. C., and Kollnos, J. J. (1946). Stages in the normal development of Rana pipiens larvae. Anat. Record 94, 7-24.

WeIss, P., and Ferris, W. (1954). Electron-microscopic study of the texture of the basement membrane of larval amphibian skin. Proc. Nctl. Acad. Sci. U. S. 40, 528-540.

Wessells, N. K. (1962). Tissue interactions during skin histodifferentiation. Develop. Biol. 4, 87-107. 